Marx's Capital 


\section{Marx's Capital}

\section{Third Edition}

\section{Ben Fine}

Reader in Economics, Birkbeck College,

University of London

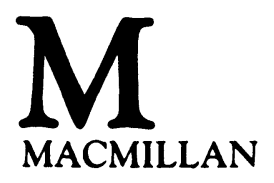


(c) Ben Fine 1975, 1984, 1989

All rights reserved. No reproduction, copy or transmission of this publication may be made without written permission.

No paragraph of this publication may be reproduced, copied or transmitted save with written permission or in accordance with the provisions of the Copyright, Designs and Patents Act 1988, or under the terms of any licence permitting limited copying issued by the Copyright Licensing Agency, 33-4 Alfred Place, London WC1E 7DP.

Any person who does any unauthorised act in relation to this publication may be liable to criminal prosecution and civil claims for damages.

First edition 1975

Reprinted 1977, 1979, 1981, 1982

Second edition 1984

Reprinted 1987

Third edition 1989

Reprinted 1990

Published by

MACMILLAN EDUCATION LTD

Houndmills, Basingstoke, Hampshire RG21 2XS

and London

Companies and representatives

throughout the world

Typeset by Footnote Graphics, Warminster, Wilts

British Library Cataloguing in Publication Data

Fine, Ben

Marx's Capital.-3rd ed.

I. Economics. Marx, Karl, 1818-1883

Kapital, Das-Critical studies

I. Title

335.4

ISBN 978-0-333-49457-8 ISBN 978-1-349-19980-8 (eBook)

DOI 10.1007/978-1-349-19980-8 


\section{Contents}

Acknowledgements vii

Preface to the Second Edition viii

Preface to the Third Edition $\mathrm{x}$

1 Method 1

The materialist conception of history 1

Marx's economics 6

2 Commodity Production 8

The labour theory of value 8

Labour and labour-power 11

The fetishism of commodities

3 The Labour Theory of Value: A Formal Analysis 16

4 Capital and Exploitation 20

Exchange 20

Capital 21

Exploitation 23

5 Accumulation 31

The coercive force of competition

The process of competition 33

The development of the proletariat 34

6 The Transition to Capitalism 38 
7 The Circuit of Industrial Capital

The money circuit of capital

The circuit as a whole 44

8 Economic Reproduction

48

9 Crises 54

The nature of crises $\quad 54$

10 On the Falling Rate of Profit 59

Summary of the argument $\quad 59$

The compositions of capital 60

The law as such and the counteracting tendencies 64

The internal contradictions of the law 65

A response to Okishio 72

11 The Transformation Problem 75

12 Banking Capital and the Theory of Interest 79

Money and merchant's capital 79

Modified prices of production 81

Merchant's capital at a more complex level $\quad 82$

Money-dealing capital and the rate of interest 83

Interest-bearing capital 84

The logical distinctiveness of interest as an economic category $\quad 87$

13 Marx's Theory of Agricultural Rent 90

Differential rent I 91

Differential rent II 93

Absolute rent 96

Conclusion 99

14 Concluding Remarks 101

Index 103 


\section{Acknowledgements}

This book is prepared from courses given at Birkbeck College on 'Marxist Economics' and 'The Distribution of Income and Wealth'. I have been influenced by those who taught and attended those courses. Bob Rae and Simon Mohun read earlier versions and have made many suggestions that I have incorporated. I thank those who have given help, but retain sole responsibility for the contents.

B.F. 


\section{Preface to the Second Edition}

This book was written in the early 1970 s and is very much a product of its time. Then, in Britain, an interest in Marx's political economy had begun to be awakened in academic circles. This interest has grown and has been fed by the decline of the world capitalist economy as students of economics have turned away from traditional theory's explanations of the collapse of the post-war 'boom'. Now in the early 1980s we can look upon a decade in which there have been many debates over the issues covered in this book. The results of these debates are necessarily absent from this text. In addition, the book was written when the author himself was still relatively new to Marx's critique of political economy. For these reasons, if the book were to be written now, it would be different. There would be differences in argument and differences in emphasis.

Nevertheless the book does have certain advantages, because of rather than despite its particular history. It is an introduction or entrance to Marx's Capital and is not the final word but rather a starting-point from which the reader can understand Marx's text and the capitalist economy. Because it was constrained to be short the arguments are condensed but remain simple, without the complications introduced by controversial debate. Although, in retrospect, embarrassing mistakes were made from place to place, I was generally surprised by the extent to which the text has survived the passage of even such a short time. This is due mainly to the fact that I attempted to reproduce Marx's ideas from Capital rather than to develop a few ideas into a 'Marxist economics'. 
I have, however, changed the text in a number of places. These are generally marginal changes, the major exceptions being the attempt to avoid sexist formulations in language (which suggested a world of men alone) and the last chapter on the world economy which has been replaced by an article, slightly amended, which first appeared in World Marxist Review in January 1980. Some errors still remain in the book but they have quite deliberately been left uncorrected for the sake of simplicity. This is perhaps most serious in the case of Marx's theory of agricultural rent. However, I have laid out my own views on this subject elsewhere: 'On Marx's Theory of Agricultural Rent', Economy and Society (August 1979) and the debate with Michael Ball in the same journal (August 1980). Otherwise a more sophisticated and developed treatment of the issues covered here and the debates to which they have given rise is to be found in the book, written jointly with Laurence Harris, Rereading 'Capital' (Macmillan, 1979). I have taken up in more detail the criticism of bourgeois economic theory and its relation to ideology in Economic Theory and Ideology (Edward Arnold, 1980) and in Theories of the Capitalist Economy (Edward Arnold, 1982).

Finally, I would like to extend my thanks to Piet Steenbakkers whose preparations for the Dutch edition of this book led to the revisions. His influence is to be found on almost every page. 


\section{Preface to the Third Edition}

The third edition has been substantially revised and extended. While some chapters have remained pretty much as before, some have been dropped altogether, some have been cut, some revised, and others have been extended. In addition, new chapters have been written to cover at greater length economic reproduction, the transformation problem, the law of the tendency of the rate of profit to fall, interest-bearing capital and rent theory. This has meant drawing upon articles from Science and Society of 1985/6 ('Banking Capital and the Theory of Interest') and from Economy and Society of 1979 ('On Marx's Theory of Agricultural Rent'). One of the effects of the revisions is to confine the book to coverage of Marx's theory as presented in Capital.

The new structure of the book is as follows. After a brief discussion of methodology in Chapter 1, Chapters 2 and 3 consider the labour theory of value (as does Chapter 11 in terms of the transformation problem). Chapters 4 and 5 examine production and accumulation, and the coverage of Volume I of Capital is concluded by examining primitive accumulation. Chapters 7 and 8 discuss the circulation of capital, and Chapters 9 and 10 are devoted to crisis theory. Chapters 12 and 13 focus on the theories of interest-bearing capital and rent respectively.

As before, the intention has been to present Marx's arguments as clearly but also as concisely as possible. These two objectives do not always coincide, with the result that some of the material will require careful reading, particularly 
the later chapters. One way of distinguishing Marx's view has been to contrast it with other schools of economic thought. This method has been employed from time to time but, hopefully, not at the expense of excluding the reader not specialised in economics. For ease of reading, footnotes and references have again been omitted. Those interested in a more scholarly text are referred to the contributions listed in the Prefaces.

Finally, I would like to thank and to encourage those who continue to study and teach Marxist economics seriously, during a period, in Britain at least, when it has been hardest to do so. 


\section{MARX TO ENGELS}

'The best points in my book are: (1) the double character of labour, according to whether it is expressed in use value or exchange value... (2) the treatment of surplus value independently of its particular forms as profit, interest, ground rent, etc.'

Selected Correspondence, Letter 99 (Lawrence \& Wishart, London, 1934).

\section{MARX TỎ J. WEYDEMEYER}

'And now to myself, no credit is due to me for discovering the existence of classes in modern society or the struggle between them. Long before the bourgeois historians had described the historical development of this class struggle and bourgeois economists the economic anatomy of the classes. What I did that was new was to prove: (1) that the existence of classes is only bound up with particular historical phases in the development of production, (2) that the class struggle necessarily leads to the dictatorship of the proletariat, (3) that this dictatorship itself only constitutes the transition to the abolition of all classes and to a classless society.'

Marx and Engels, Selected Works (Lawrence \& Wishart, London, 1968) p. 679. 